\title{
Non-compliant Reading and Annotating in the Ruthenian Reformation: Cyril of Jerusalem's Mystagogical Catechisms from Szymon Budny's Library
}

\author{
Maria Ivanova \\ McGill University
}

\begin{abstract}
While the works of the Antitrinitarian thinker and religious leader Szymon Budny (ca. 1530-93) have been the subject of extensive scholarly research, his library, marginalia, and reading practices have been significantly less examined. Following the discovery of a copy of Cyril of Jerusalem's Mystagogical Catechisms (Vienna, 1560) belonging to Budny, I analyze Budny's notes and comments regarding the Latin translation of Cyril's text as a case study of Budny's attempt to recover the Church Father from the Catholic post-Tridentine agenda and his own subsequent reappropriation of Cyril for his radical non-adorantist program. By exploring Budny's subversive reading and annotating strategies, I demonstrate Budny's original contributions to the development of Antitrinitarian thought in Europe. I also illustrate how marginalia and paratexts reflect not only the history of the book in which they are found, but also how they throw light on religious and intellectual history.
\end{abstract}

Keywords: Szymon Budny, Cyril of Jerusalem, Reformation, Antitrinitarianism, marginalia.

\section{INTRODUCTION}

\section{$\mathbf{T}_{\mathrm{h}}$} he legacy of the renowned Ruthenian Antitrinitarian ${ }^{1}$ thinker and radical religious leader, Szymon Budny (ca. 1530-93), has been of interest to many scholars. Although Budny's works-his biblical translations, his commentaries on the Christian Bible, his political and religious treatiseshave been analyzed at length, books from his library and his marginalia have not been comprehensively researched. Their detailed examination would result in a deeper understanding of Budny's exegetical methods and his ways of reading and interpreting texts that were characteristic of early modern intellectuals in Ruthenia. Budny's marginalia also demonstrate his original contributions to Antitrinitarianism in Eastern Europe.

\footnotetext{
1 The notion "Antitrinitarianism" refers to religious groups during the Protestant Reformation that rejected the Christian doctrine of the Trinity.
} 
Budny and his circle were among the first Reformation thinkers to read, reflect on, and critically engage with the newly printed works of Cyril of Jerusalem, as the manuscripts of this Church Father had been for centuries unknown in western Europe. The first goal of this article is to present Budny not only as a radical, subversive writer, but also as a subversive reader and annotator. His marginalia and linguistic comments highlight the importance and the necessity of studying paratexts in an early modern book. They serve as evidence, independent from primary texts, not only in the context of the history of the book, but also in the context of church history, given that the theological positions were often shaped in the language itself. My second goal is to showcase the significance of eastern European religious and intellectual thought in the history of the reception of the patristic legacy.

\section{AN UNKNOWN BOOK FROM SZYMON BUDNY'S LIBRARY}

We do not possess extensive knowledge of Budny's library. Was it large (Pietrzyk, "Szymon Budny" 57; Saverchanka 58)? Or did he rely on the collections of the Radziwiłł library, as well as other private libraries in the Grand Duchy of Lithuania (Podokshin 128)? Only three books belonging to Budny were known until the early 1990s when a fourth one, Novus Orbis, was discovered. Zdzisław Pietrzyk provided a general description of this work, as well as an overview of Budny's marginalia. Pietrzyk suggested that analysis of these marginalia together with the marginalia in other books from Budny's library might help in creating an "intellectual portrait" of one of the most influential Polish-Lithuanian "heretics" (Książka z biblioteki 61).

There is, in fact, a fifth surviving book, which belonged to Budny. While on a research trip to the Library of Kornik (Biblioteka Kórnicka), I discovered a copy of the 1560 edition of Cyril of Jerusalem's Mystagogical Catechisms (Cim.Qu.2784, [Piekarski 44]) that had belonged to Szymon Budny, and that contains Budny's notes and marginalia (Figure 1). 
Figure 1: The title page of the Mystagogical Catechisms (Vienna, 1560) from the Kórnik Library (Cim. Qu. 2784). The annotations in red ink belong to Szymon Budny. The image was provided courtesy of the Kórnik Library with the assistance of Grzegorz Kubacki.

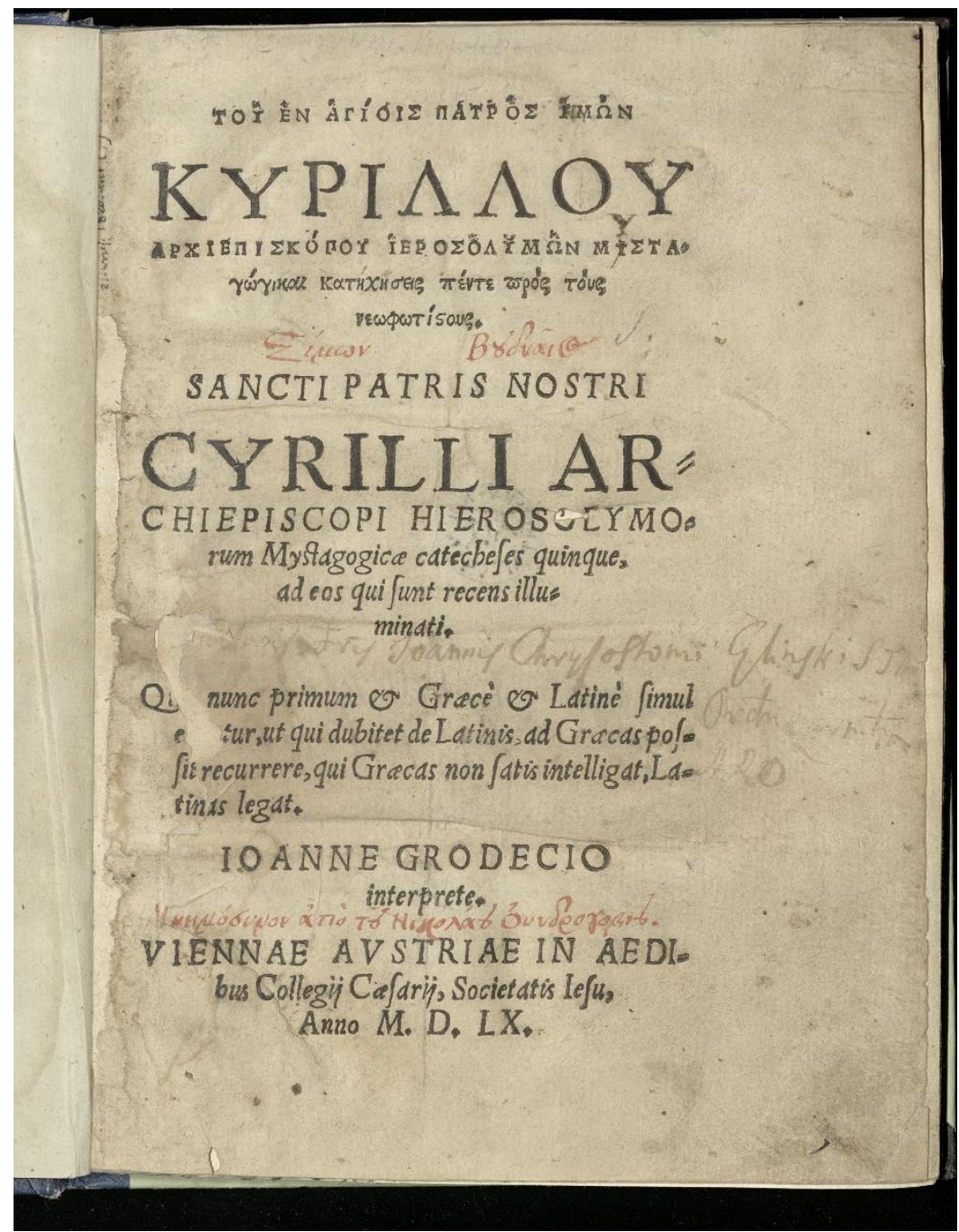

The handwriting and the character of the notes in Mystagogical Catechisms (hereafter denoted MCs) are identical to those in Novus Orbis (see below). Budny's marks and notes, as in the case of Novus Orbis, are in bright 
red ink and thus are readily distinguished from layers of marginalia belonging to other readers (for more information on the provenance of this book, see Muszyński 169). Budny's handwriting is almost always legible, as it belongs to someone who engaged professionally in writing but also in reading. Budny was a new type of secularized thinker and scholar; he was also a professional commentator, beyond the domain of religious exegesis sensu stricto. The only instances in which Budny's marginalia are illegible occur when wear and tear or preservation measures taken for book

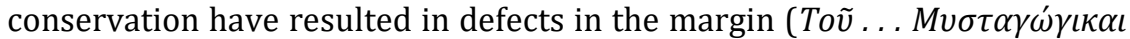

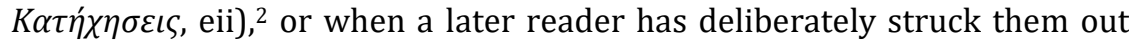
due to their radical and highly polemical nature. Today we know of five books belonging to Budny:

1. Gratianus, Decretum, cum apparatu Bartholomaei Brixiensis (Basel: Johann Froben \& Johann Amerbach, 1500);

2. Publius Ovidius Naso, Tristium libri, cum commantario Bartholomaei Merulae (Venice: Johannes Tacunius, 1499);

3. Petrus Galatinus, Opus de Arcanis catholicae veritatis, hoc est: in omnia difficilia loca Veteris Testamenti ex Talmud aliisque Hebraicis libris quum ante natum Christum tum scriptis contra obstinatam Judaeorum perfidiam absolutissimus commentarius. Ad haec Ioannis Reuchlini Phorcensis l.l. divertoris de arta cabbalistica libri tres de verbo mirifico omnigena eruditione pleni (Basel: Johan Hervagius, 1571) (a description of this volume can be found in Kantak);

4. Novus Orbis regionum ac insularum veteribus incognitarum, una cum tabula cosmographia et aliquot aliis consimilis argumenti libellis, quorum omnium catalogus sequenti patebit pagina (Basel: Johan Hervagius, 1537).

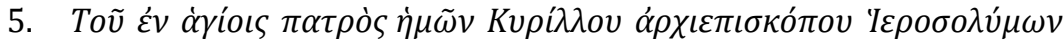

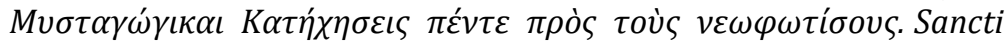
Patris Nostri Cyrilli archiepiscopi Hierosolymorum Mystagogicae catecheses quinque ad eos qui sunt recens illuminati. Quae nunc primum et Graecè et Latinè simul eduntur, ut dubitet de Latinis ad Graecas possit recurrere, qui Graecas non satis intelligat, Latinas legat. Ioanne Grodecio interprete" (Vienna: In aedibus Collegii Caesarii, Societatis Jesu, 1560) (further - MC).

${ }^{2}$ All further references to this edition will be provided as page numbers in brackets. 


\section{THE VIENNA 1560 EDITION}

Five post-baptismal sermons were delivered by patriarch Cyril ${ }^{3}$ during the Paschal week at the Church of Resurrection in Jerusalem around the 370s (with 382 as terminus a quo for MC 5). The sermons deal with the rites of baptism, chrismation, and eucharist. The 1560 publication was an editio princeps (istae nunc primum in lucem prodeunt [A]) and thus a turning point in the history of the reception of Cyril's sermons in the Catholic west. While the Orthodox east knew of Cyril's MCs in several Greek copies (some of them dating back as early as the tenth century), as well as the Slavonic translations, the west was oblivious to these works until the sixteenth century, when the catechisms were published in Vienna under the full title "Five mystagogical catechisms of our saint father Cyril, archbishop of Jerusalem, for those who have recently been enlightened [in the Christian faith, i.e. baptized]. Which were now printed for the first time in Greek and Latin simultaneously, so that those who doubt the Latin [text] can have recourse to the Greek, and those who do not understand Greek well enough, can read in Latin. The translator is Jan Grodziecki." 4 The publication was strongly linked to the Council of Trent (1545-63) and was used as a polemical tool against Protestants, who doubted the authenticity of the MCs (Vaillant 280). For a long time this edition did not receive much attention, partially because of the difficulty in locating it; Touttée, in the preface to his Latin translation, confesses to having been unable to trace it (Touttée aii), and Piédagnel in his critical Greek edition with French translation calls it "lost" (Piédagnel 44).5

Jan Grodziecki (1525-96), a Polish philologist well-versed in Greek, was secretary to Cardinal Stanislaus Hosius and later became Bishop of Ołomuniec, (today Olomouc) in the Czech Republic (Syrokomla 243; Niesiecki 386-87). It was at Hosius's encouragement that Grodziecki published his bilingual version (Aiii). The translation was based on two Greek manuscripts (Bihain 26-36, 114-18). The primary manuscript was the sixteenth century Ottoboni, gr. 220 (Vatican Library), which was copied by Jean Nathanaël from the eleventh century Ven. 35 (National Library of St.

\footnotetext{
3 These five sermons are identified in this study as MC1, MC2, MC3, MC4, and MC5. I omit the discussion of Cyril's authorship of the MCs, as it is beyond the scope of this study.

${ }^{4}$ Translations are mine, unless otherwise indicated. For the English text of the MCs, I have used Cross's St. Cyril of Jerusalem's Lectures.

5 Indeed, the book is rare: apart from Kórnik, a few other copies are located, according to WorldCat, in the Catholic University in Lublin, the Catholic Institute of Paris, Poitiers University Library, Linköping City Library, Austrian National Library, National Library of the Czech Republic, and Durham University Palace Green Library.
} 
Mark in Venice). Ott. 220 was also used by Grodziecki's patron Hosius in his Confessio catholicae fide Christiana (Christian Confession of the Catholic Faith) - the work, which had thirty editions during his lifetime and was translated into almost all western European languages (Umiński 400): the Greek text of MC 4 was printed alongside Cardinal Guglielmo Sirleto's (151485) Latin translation (Formanowicz 20). This first manuscript, because of mutilations (mendosum admodum, et multis in locis mutilum exemplar), was corrected on the basis of Ottoboni, gr. 86, originating at the Monastery of Stoudios in Constantinople around the ninth or tenth century (Aiii). After the crusades, Ott. 86 was transferred to the Monastery of Saint Mary of Patir in Calabria, where it was found by the Spanish Jesuit polemicist and Hellenist Francisco Torres (ca. 1509-84), renowned for his discoveries of the works of the Church Fathers (Pérez Goyena 783). Guglielmo Sirleto, Calabrian in origin, a renowned linguist, scholar, and librarian of the Vatican library, where he prepared a complete catalogue of its Greek manuscripts (Weber 27), ordered Ott. 86 to be relocated to the Vatican, no earlier than June 1559 (Kadochnikova 51).

Upon completing his translation, Grodziecki learned from Jakub Uchański (1502-81), the primate of Poland, that the latter had discovered a Slavonic manuscript of all Cyril's Catechisms in Macedonia. Uchański translated the manuscript into Polish and gave it to Grodziecki, who compared all the versions available to him and proclaimed a miraculous textual unanimity among all the texts and versions (ex mirabili quadam concordia diversae linguae, \& translationis) (S. Patris Nostri ... Catecheses A3$A 3^{v}$ ). In 1564, on the basis of these new sources, Grodziecki published the full translation of Cyril's Procatechesis, eighteen catechetical lectures, five mystagogical catechisms, and a "Letter to Constantius." 6

\section{MIKOŁAJ WĘDROGOWSKI}

The title page of the Kórnik copy bears an inscription in Greek, made by Budny. First, his name appears between the Greek and Latin titles: $\Sigma \iota^{\prime} \mu \omega v$

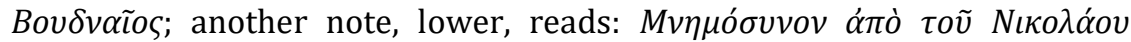

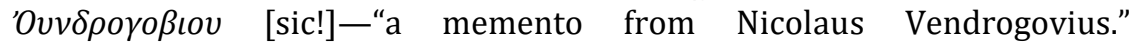
Vendrogovius, or Mikołaj Wędrogowski, the previous owner of the book, deserves a separate account, as not only is he a prominent actor in the history of the Reformation in Poland-Lithuania and, more specifically, in the history of the dispute about infant baptism, but he also bears traits of a

\footnotetext{
6 The 1564 edition was published in Paris, Cologne, and Antwerp (with the latter quoted above).
} 
flexible, protean mentality that was characteristic of the epoch and, on many levels, quite similar to Budny's mentality.

During the Pińczów Council in May 1560, Wędrogowski, a Calvinist minister in Wilno (Vilnius), spoke about the idea of a united Protestant church (Węgierski 146, 537). According to the vision of prince Mikołaj Radziwiłł, a patron of the Reformed churches in the Grand Duchy of Lithuania, such a union between the Reformed and the Lutheran churches would go even beyond Poland-Lithuania and include Prussians and Livonians (Petkūnas, Holy Communion Rites 153). As an ardent supporter of Calvinism, Wędrogowski wrote a letter to Calvin in 1561, calling him singulare orbis decus ("the unique ornament of the Earth") and offered his "promptitude" (Baum et al. 81).

However, Wędrogowski was among those who later shifted to the radicalizing circle that included Budny. According to Budny's account in the "Short excerpt about infant baptism," upon reading the books of Piotr of Goniądz, Wędrogowski started to ardently reject the necessity of paedobaptism ("O dzieciokrzczeństwie"). Budny describes Wędrogowski as "timorsome," influenced by others and prone to changing his opinions ("O dzieciokrzczeństwie" 105). Wędrogowski's inconstancy led to a conflict with Marcin Czechowic, an opponent of infant baptism and the author of the polemical work Trzech dni rozmowa o niektórych artykułach tych czasów wzruszonych (Three-Day Conversation about Some Articles of Faith Touched upon Nowadays). Incidentally, this work, published in 1578, long after Wędrogowski's death, included the latter's Wotum... o chrzcie małych dziatek (An Opinion on the Christening of Small Children) (Szczucki 94). Mikołaj Radziwiłł reprimanded Wędrogowski "for frequent changes in the Church" (Budny, "O dzieciokrzczeństwie" 106). According to Budny, Wędrogowski in his testament argued against infant baptism, thus presumably sharing Budny's stance. Wędrogowski died in 1566 during an "epidemic" (powietrze); given that the Mystagogical Catechisms were a $\mu \nu \eta \mu o ́ \sigma v v o v$ ("a memento"), it is likely that Budny read and annotated the book no earlier than 1566 (Budny, "0 dzieciokrzczeństwie" 108).

Wędrogowski's vacillations between the Calvinist ecclesia maior and the Antitrinitarian ecclesia minor within the Polish Reform, were not left unnoticed by later generations of the movement. Stanisław Lubieniecki (1623-75), a Polish Socinian theologian and author of the famous Historia reformationis polonicae (History of the Polish Reformation, 1685), writes the following:

the memorable case of Nicholas Wędrogowski demands our attention. For as death drew near, he confessed to having committed the crime of hypocrisy [hypocriseos crimen] before God. When asked how, he replied that though he called himself a minister of the heavenly Lord, yet he often 
taught in hope of winning not His favor, but that of men, and he cried out: "My praise is turned to shame, because I have sought my own glory, and not God's." So Budziński records it. No wonder that he was omitted by Andrew Węgierski in his Historia Ecclesiastica. (Lubieniecki, Historia reformationis polonicae 189; Lubieniecki, History of the Polish Reformation 236). ${ }^{7}$

Similar views on Wędrogowski's "hypocrisy" have been expressed by later scholars (Domański and Szczucki 238).

The name of Wędrogowski appeared on the 1603 Clement VIII's Indexthe first Polish index of prohibited books. None of Wędrogowski's works are known to have survived (Guzowski 199). At any rate, despite his vacillations in religious beliefs and the accusation of hypocrisy cast by Lubieniecki, Wędrogowski remains a figure emblematic of the era. Being considered "le vice du siècle," hypocrisy was a "ubiquitous phenomenon in the moral horizon of the seventeenth century," with an easy extrapolation to early modernity in general (Bos 65). Budny's opprobrium should also be taken with reservations, especially given the latter's own record of engaging in dissimulative practices, including but not limited to his reading strategies (Ivanova 34-41). I return to the discussion of "hypocrisy" later, as it will help to contextualize Budny's reasons for non-compliance.

BUDNY'S MARGINALIA ${ }^{8}$

\begin{tabular}{|c|c|}
\hline Title page & 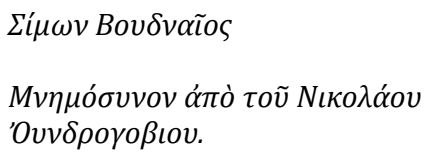 \\
\hline MC 2 & \\
\hline 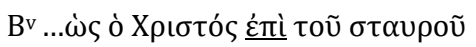 & $\alpha \dot{\pi} \pi \dot{\theta}$ \\
\hline 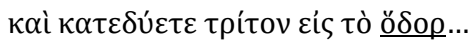 & v̌ $\delta o \rho$ \\
\hline
\end{tabular}

\footnotetext{
${ }^{7}$ While Andrzej Węgierski (1600-49), a Calvinist historian of the Slavic Reformation, chose to not include the name of Wędrogowski in his Historia Ecclesiastica, he does mention him in the list of ministers (right before Budny) in the Libri quattuor Slavoniae reformatae, as noted earlier.

8 (M) indicates the text printed in the margins. Budny's handwritten notes are in cursive. Page numbers are given according to bottom right pagination.
} 


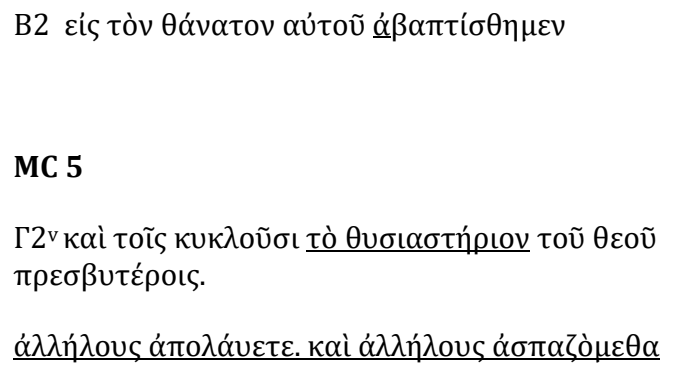

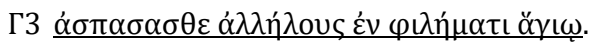

$\underline{\alpha} v \omega \tau \grave{\alpha} s, \kappa \alpha \rho \delta i ́ \alpha c$.

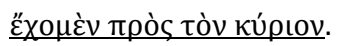

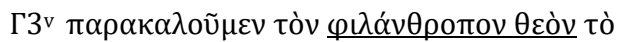

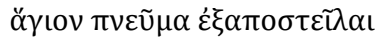

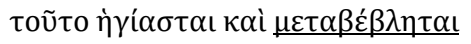

\section{Preface to the Latin translation}

$\mathrm{A}^{\mathrm{v}} \underline{\text { hoc, }}$ inquit, $\underline{\text { Servatoris oraculum adimplebitur }}$

Et cum multi ad miraculum Iudaei convenissent, ignis coelitus delapsus, cuncta artificium instrumenta consumpsit.

Aiiiv ....novatores nostri temporis, intelligant res antiquas et sanctissimas esse, et ante tot saecula in Ecclesia Catholica receptas et usitatas fuisse...

\section{1}

$\mathrm{Bi}{ }^{*}$ Vespere ${ }^{\text {Primum }}$ ingressi estis in porticum domus $\underline{\text { baptisterii }}$
Si sanctissimae sunt hae ceremoniae, Grodeci, quin igitur etiamnum fiant apud tuos Papas?

consule Graecum exemplar et hoc loco et ubique

* ut quem illo vespere in vobis facta est, baptismi vim perspicatis 
Biii Epanis erat et vinum merum

Biiiv [Professio fidei] CREDO in Patrem et Filium et Spiritum Sanctum, et in baptisma poenitentiae

\section{2}

Biii in intere ${ }^{i}$ ore domo peragebantur

Biiiiv 0 rem admirandam: nudi fuistis in conspectu omnium, et non vos pudebat.

$\mathrm{Ci}^{\mathrm{v}}$ et per hosce tantos dolores, mihi nihil eiusmodi patienti salutem confert

\section{3}

Ciiv et Spiritus Sanctus substantialiter super eum descendit: requiescens super sui similem

Ciii [Coeterum vide ne illud esse putes unguentum tantum...]

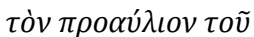

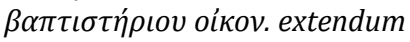
erat in porticum baptisterii domum

Eante sanctam invocationem adorandae trinitatis, ${ }^{E}$ Nam sic Graeca sunt

Baptisma poenitentiam dicit. Atqui infans poenitentiae minime est capax. Ergo neque baptismi.

(M) Baptizandi vestibus exuistis, nudierant.

Baptizandi nudi stabant coram omnibus

in Graeco non invenitur

Nota

(M) Panis Eucharistiae post consecrationem fit corpus Christi 


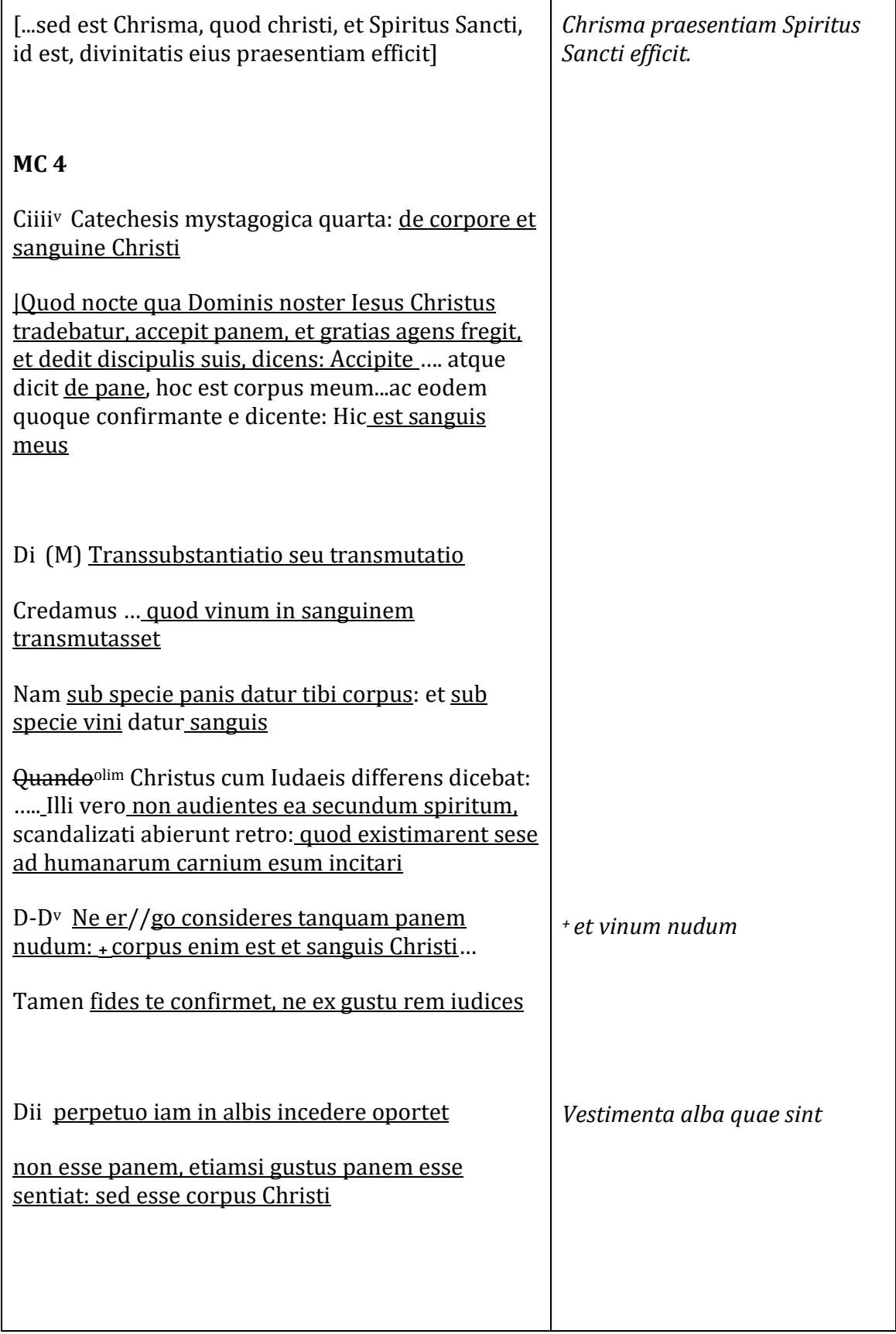




\section{5}

Diiv Vidistis igitur Diaconum aquam lavandis manibus porrigentem Sacerdoti, et illis qui circum altare Dei stabant, Presbyteris.

Dii Deinde clamat Diaconus: Osculemini nos invicem, atque tunc mutuo nos osculo salutamus.

Postea clamat Sacerdos: Sursum corda.

Vos deinde respondetis: Habemus ad Dominum.

Diiiv Dicit deinde Sacerdos: Gratias agamus Domino.

Ad haec vos subiicitis: Dignum et iustum est.

Facimus deinde mentionem coeli, et terrae, et maris, solis et lunae, et syderum, ac universae creaturae.

Sanctus, sanctus, sanctus Dominus Deus Sabaoth.

(M) Seraphica hymnodia

Diiii

...ut panem quidem faciat corpus Christi; vinum vero sanguinem Christi. Omnino enim quod attigerit Spiritus Sanctus, hoc sanctificatur et transmutatur.

obsecramus Deum, pro communi Ecclesiarum pace, pro tranquillitate mundi, pro aegrotis et afflictis, et in summa pro his omnibus qui egent auxilio.

...ut meminerimus etiam eorum, qui ante nos obdormierunt.

$\underline{\text { Oratio pro defunctis. }}$

Sanctorum invocatio.

(M)Transmutandi vis à Spiritu $\underline{\text { Sancto }}$

Sanctorum invocatio




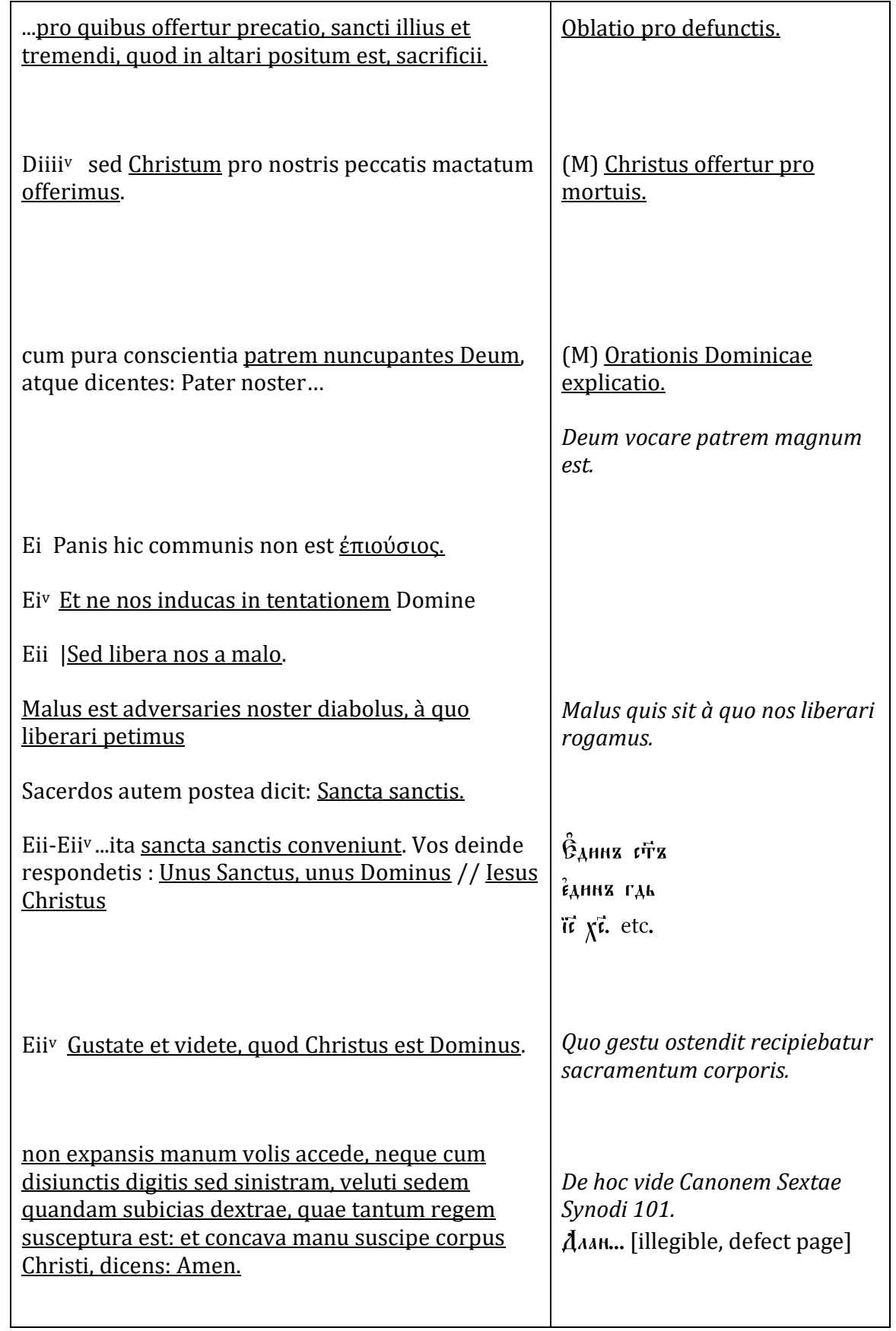




\begin{tabular}{|c|c|}
\hline $\begin{array}{l}\text { Tum vero post communionem corporis Christi, } \\
\text { accede et ad calicem sanguinis illius, non } \\
\underline{\text { extendens manus }}\end{array}$ & $\begin{array}{l}\text { Observa aetate huius Cyrilli } \\
\text { calicem non fuisse laicis negari } \\
\text { solitum. }\end{array}$ \\
\hline $\begin{array}{l}\text { Eiii cum adhuc est humiditas in labiis tuis, } \\
\text { manibus attingens, et oculos, et frontem, et reliqua } \\
\underline{\text { sensuum organa consecra. }}\end{array}$ & Superstitio. \\
\hline $\begin{array}{l}\text { à communione vos non praecidatis: neque propter } \\
\text { inquinamentum peccati, sacris hisce } \\
\text { spiritalibusque mysteriis vos ipsos privetis }\end{array}$ & $\begin{array}{l}\text { À coenae Dominicae } \\
\text { participatione non } \\
\text { abstinendum, etsi peccatis } \\
\text { deterrearis. }\end{array}$ \\
\hline
\end{tabular}

Budny's marginalia do not always reveal his explicit stance toward a particular liturgical issue or theological problem, in stark contrast with his notes in Novus Orbis. We have to rely on the underlining of words and phrases that seem to be of interest to him, or corrections of grammar and spelling (Eiiii), including corrections following the errata already provided in the text (Di), or following a summary of a paragraph. The Greek text has only a small number of spelling corrections. The fact that the majority of notes and marginalia are found in Latin text rather than in Greek text, suggests that Budny's predominant interest was not solely in the content of the Catechisms, but also in the Latin translation.

As mentioned earlier, the 1560 edition of MC was intended to be used against the Protestants. According to Grodziecki, Torres "lauded" Cyril's sermons and deemed them extremely useful "for the doctrines of the Catholic church, which are now being shattered by the sectarians" (ad Ecclesiae catholicae dogmata, quae nunc à sectariis convelluntur) (Aiii). In the Tridentine and post-Tridentine periods, Church Fathers were often used as a polemical device to serve the cause of the Counter-Reformation, while the Catholic Church strived to reclaim the patristic heritage and ascertain the continuity between the patristic legacy and church practices (Keen 701-09). This engendered not only a heightened interest in the rediscovery of the manuscript tradition: eminent theologians and thinkers also authored Latin translations of the texts of the Fathers, a notable example being the aforementioned cardinal Sirleto, who translated the works of St. Basil (Backus and Gain 933). Often, however, translations were made to serve the demands of Catholic theology, and Greek Fathers were "appropriated." Latin translations "westernized" the Greek (Church) Fathers, giving them different accents: the translations were rather interpretations of texts "in light of Latin position" (Backus 317). 
In his preface, Grodziecki aimed to defend the continuity between the practices of the early church and Catholic religious ceremonies (ante tot saeculas in Ecclesia Catholica acceptas et usitatas fuisse). (In the 1564 edition, the miraculous concordia between various Cyrillian texts and translations would justify the "veracity" of the institutions he wrote about and, hence, likewise the Catholic ones.) It would not come as a surprise that the most immediate goal for Budny was to demonstrate the rupture, rather than the continuity, and that he reacted with a sarcastic invective: "If these ceremonies are most sacred, Grodziecki, why not perform them even now among your Popes?" (Aiiiv). This statement was echoed in his 1572 Bible where he sought to undermine the continuity between the priesthood of the biblical Samuel and Zechariah and the Roman clergy (Budny, Biblia Biiii). To dismantle the Catholic line of argumentation, Budny used a three-pronged strategy.

The first prong of his argumentation was aimed at undermining the Latin renderings of church terminology. For example, he compares the 1560 rendition of the Greek word $\tau$ ò $\theta v \sigma \iota \alpha \sigma \tau \eta \dot{p} \iota \iota v$ with the Latin, altar, in MC 3 (we see the comparison through his underlining of the respective words).

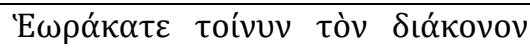

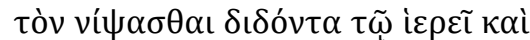

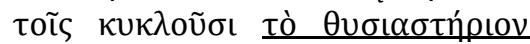

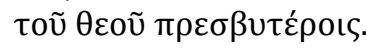

Vidistis igitur Diaconum aquam lavandis manibus porrigentem Sacerdoti, et illis qui circum altare Dei stabant, Presbyteris.

In the Vienna edition, the place where sacrifices were made ( $\tau \dot{o}$

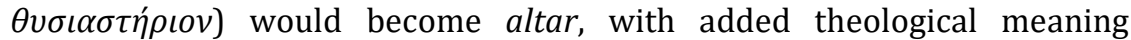
reflecting the Tridentian decrees on the "sacrament of the altar." For Budny, as a representative of the radical wing of the Polish-Lithuanian Reformation, a different terminology was needed that would have no link to the tradition of the Catholic ("Trinitarian") usage. Patristic legacy served as a source for such terminology.

In 1564, Budny and another Ruthenian printer Laurentsii Kryshkouski published a Polish translation of the second century apologetic text Rozmowa z Żydem Tryfonem-Justin Martyr's Dialogue with Trypho. There, they follow the Aristotelian tradition by claiming that not understanding the meaning of words equals not understanding the analyzed issue, expressed in these words: "The Philosopher writes that the one who does not understand words well, will easily become mistaken in the thing itself" (Kryshkouski et al. CIII). Thus, "having the right words and understanding them correctly" becomes the goal. The human capacity to know implies one's ability to "understand words," to discern between meanings and to operate 
with those meanings. This implies a knowledge of etymology when words are being placed in a historical, diachronic context. Only one who knows the history of a word, the context of its usage, and its applicability possesses true knowledge. Here, Budny is not just a reader-controversialist entering into the polemics, he is also a humanist, whose reading of the Fathers as fontes rather than as autoritates was part of a larger humanist project to revive the ancient legacy and critically engage with early Christian texts (Stinger 47475).

In his later writings, such as his 1583 O urzędzie miecza używającym (On the Defense of the Sword), Budny takes up the same line of thought, making a link between understanding words and understanding things, and praising the importance of grammar and etymology (107). In his account of the dispute on the admissibility of serfdom, Budny draws parallels between the

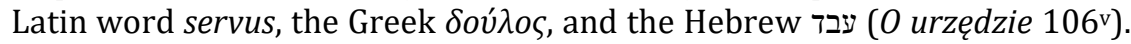
He further compliments one of his interlocutors regarding his analysis of servus: "you have spoken well, brother, and you have shown the etymology of this word well" (Budny, $O$ urzędzie 107v).

In his preface to a 1574 edition of the New Testament, Budny refuted existing translations of the Bible (including the Polish ones), on precisely the same etymological grounds. He deemed unacceptable the translations of presbiter and sacerdos as kapłan and of ecclesia and templum as kościót, but for a reason different from the Kraków Bible translator's presumed lack of proficiency in Latin (Budny, Nowy Testament Ciii). Budny and other Reformed thinkers called for a return, not only to the "original" apostolic Church, but also to the original meaning of words. Instead of kościót 'church' Budny insisted on zbór 'meeting'; he also substituted ofiarownik 'the one making sacrifices' for kapłan 'priest', referring to a church official. Here, Cyril apparently supplied Budny with rich material. One cannot help but ask if the

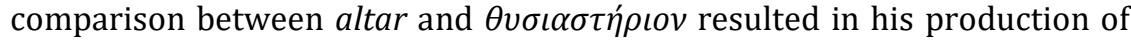
the Polish word ofiarownik, modelled after the Greek words $\theta v \sigma i ́ \alpha$ and ofiara, both of which mean "offering," "sacrifice." 9

Budny's strategy focused on finding textual discrepancies between the Greek text and the Latin translation. The front page of the Vienna edition of the MC bears an inscription: "so that this one who would doubt the Latin [text], could find recourse to the Greek one, and the one who does not understand Greek sufficiently, would read Latin." While the second part of the inscription was definitely not the case with Budny (his marginalia in the Greek version include some corrections of grammatical mistakes, which, incidentally, were not found in later editions), Budny followed the instructions of the first part of the inscription quite diligently. He was indeed

${ }^{9}$ For a discussion of Budny's views on etymology, see Paretski 97-100. 
the "doubtful" reader of the Latin translation. It would seem that he was not only interested in the contents of the $\mathrm{MC}$, but in the character of the translation itself.

While reading MC 1, he makes a marginal note: "Consult the Greek variant in this place and everywhere" (consule Graecum exemplar hoc loco et ubique) (Bi). This "everywhere" becomes a powerful representation of Budny's approach to reading and interpreting texts. The doubt will come to be fully implemented in his subsequent works, arguably the most wellknown being his commentary to the 1574 biblical translation: "examine everything" (wszego sprawdzajcie), a reference to 1 Thes. 5:2 (Budny, Nowy Testament Ji ii).

In MC 2, he notices a discrepancy between the Latin text and the Greek text: in the phrase "while to me without suffering or toil, by the fellowship of his pain he vouchsafes salvation," the words mihi nihil eiusmodi patienti (to me without suffering or toil) are not included in the Greek text on p. B2 (Cross 61).

For Budny, such discrepancies were arguably more than evidence of inaccuracies in the Latin translation, they were a sign of a translation with an agenda. For example, the omission of the phrase "and bare wine" (et vinum nudum) - inserted by Budny in the margin - was evident in the text of MC 4: "Contemplate therefore the bread [and wine] not as bare elements, for they are ... the body and blood of Christ" (D-Dv). Here we observe the third prong of Budny's strategy: to demonstrate the inauthenticity of Catholic rites and ceremonies and their inadequacy to Cyril's formulae. In the example above, the omission of the phrase et vinum nudum may have been suggestive of the Catholic doctrine of a communion under one kind (only consecrated bread) for the laity. This is echoed in Budny's marginal note in MC 5, which pointed out that at the time of Cyril there was no practice to deny the chalice to laypeople (Eiiv). The Protestants commonly referred to the practice of offering a communion under both kinds only to priests as a justification of the clergy's hierarchical status.

A discussion of Budny's textological observations calls for mentioning his language choice for the marginalia. While not matching the quadrilingual gamut in the Novus Orbis (which includes Polish), Budny's marginalia were written in three languages-Greek, Latin, and Church Slavonic. Budny's use of Greek for signing his name is indicative of several possible motives. Given that it appears right after the Greek version of the book title, it can be interpreted as Budny's siding with the Greek version (at least here), at the expense of the Latin version: hence his call consule Graecum exemplar. The language shift occurs not just because he comments on the Latin text, but because he enters into a direct dialogue with Grodziecki (the translator) acting as a synecdoche for corrupt translators whom Budny would criticize at length in his biblical prefaces in the 1570s. 
It is possible to attribute the use of the Greek or the Church Slavonic at least partially to Budny's extensive use of the Orthodox dogma as a polemical tool in his earlier writings. In 1563, Budny sent a letter to Heinrich Bullinger seeking to obtain Bullinger's position on filioque (Budny, Littera ad $H$. Bullingerum). By offering his own approach to refuting the filioque with the "help" of the Orthodox doctrine of the procession of the Holy Spirit from the Father alone, he must have hoped to use the answer of the Swiss theologian in the intra-confessional debates in Poland-Lithuania (Kamieniecki 73). In general, the Reformers not infrequently referred to the liturgy still in use among the Orthodox as justification for charges against the Catholic church of dogmatic and liturgical innovation (Hall 172). It might also have been due to Budny's familiarity with the cultural and religious practices of the Orthodox Rus': his first two works were published in Cyrillic and were arguably geared toward promoting the Reformed agenda among the Orthodox. Budny's marginalia in Cyrillic (again, defective because of preservation work) most likely offer a parallel text to $\mathrm{MC}$. Is it possible that Budny had access to a manuscript with a Slavonic translation of Cyril's text and thus made a double comparison?

However, it is more likely that Budny read not only for criticism or comparison, but "for action" (Jardine and Grafton): the patristic text and its translation become Budny's textual laboratory, a springboard for developing and articulating his own agenda, as disinterested engagement was, indeed, "difficult to sustain in the age of confessionalization" (Taylor). The eastern Christian practices come under the attack as much as the western practices for being inauthentic. Budny makes note of a difference in the liturgical practices of his own time in comparison to Cyril's time. For example, his marginal inscription "by what gesture the sacrament of the body is received," draws attention to the practice of the faithful accepting the Host in their hands-a practice shared by Calvinists and Antitrinitarians (Eiiv). What seems of importance to Budny, is the absence of the holy spoon, or cochlear, which is used in the Byzantine rite to administer the communion to the laity, and which was first attested in the ninth or, more likely, the eleventh century (Taft 238). Here, Budny instructs the reader to consult the decrees of the Sixth Ecumenical Council (the Third Council of Constantinople): more specifically, decree 101, mentioned by Budny, prohibits the use of precious (golden) receptacles to accept the Host and encourages the faithful to use their hands. Detailed references should, however, not be misleading in regard to Budny's motives: upon expediently and conveniently adducing evidence from Cyril's liturgy, in his marginal comment he straightforwardly and unambiguously summarizes the passage on touching the eyes and hands with the moisture from the eucharistic blood after receiving communion as "superstition" (Eiii). 
The Church Fathers' writings were deployed in many of the religious debates of the time, including the intra-Protestant debates in PolandLithuania. In 1565, for example, at the Diet of Piotrków debate between the Reformed and the Antitrinitarians, the former extensively appealed to the Fathers and the early Councils (Petkūnas, "Polish and Lithuanian" 103). Thus, for Budny, the study of the Church Fathers might have been a conscious step toward re-appropriating the patristic legacy as a tool against the Catholics or Orthodox-and also against the Reformed with whom he openly parted ways in 1567 upon publicly proclaiming his Antitrinitarian views. Of importance in this context is Budny's marginal note on p. Biiiv, accompanying the text: "I believe in the Father, and in the Son, and in the Holy Ghost, and in one baptism of repentance" (Cross 58). The note is as follows: "He said, 'baptism of repentance.' However, an infant is minimally capable of repentance. Hence, [minimally capable] of baptism." His reflections on the text of the MC (MC 2, in particular) might have played an integral role in the development of Budny's argumentation against the baptism of infants. ${ }^{10}$ Discussions of the baptismal ritual, and related etymology, shaped the earlier stages in the forging of the Antitrinitarian identity in the Polish-Lithuanian Commonwealth, and Cyril of Jerusalem was one of the early voices in the development of baptismal theology (Williams 649; Łuszczyńska).

Still, most significantly, we see in Budny's notes the forging of his own radical non-adorantist views, which went beyond those of his co-religionists. The marginal note "It is great to call God (our) Father," that accompanies the words patrem nuncupantes Deum in Cyril's exegesis of the Lord's prayer in MC 5, arguably foreshadows Budny's statement that God the "Father is the only true God" (Diiiiv). Likewise, in the Greek text of the epiclesis in MC 5,

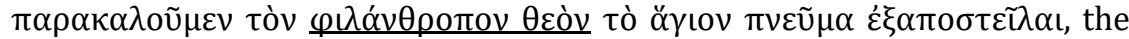
underlined words in "we call upon the merciful God to send forth His Holy Spirit" served presumably to show the invocation of God the Father, who sends the Holy Spirit (Cross 74). In a similar vein, in the passage from MC 3, "and the Holy Ghost in substance lighted on Him, like resting upon like" (Cross 64), underlined and conveyed by the exhortation to "note" [Nota] (Ciiv), Budny presumably notices the terminology "like" (similem, ónoíov) rather than "consubstantial" (consubstantialis, ò the second and third persons of the Trinity at the Nicea and Chalcedon Councils. Incidentally, Cyril is deemed to have used ó this one instance may have been an interpolation (Yarnold 60). The lack of precision in the religious terminology, Christological and Trinitarian above

10 In his 1562 Catechism, Budny still reluctantly allows for infant baptism (Budny, Katekhizis 230v). 
all, which would result from the work of Ecumenical councils, allowed a liberal interpretation of Christian dogma (Kamieniecki 83). While this failure

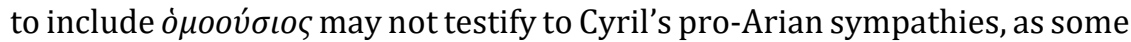
have suspected, ${ }^{11}$ omission of this terminology might have armed the Arian Budny with a loophole for his programmatic arguments against "trinitarians" (trójczanie) (Budny, O przedniejszych 28) and the "homoousian sect" (homouzyańska sekta) (Budny, Nowy Testament Ciiii).

Of similar significance is Budny's particular interest in the text of MC 5, which contains a structure of the Jerusalem anaphora, or the eucharistic prayer. Budny's underlining, coupled with topical or summarial notes, carefully follows the main parts of the anaphora: the preface, the sanctus, the epiclesis, and the intercessions. The striking feature of this anaphora, the absence of the institution narrative, ${ }^{12}$ could not have escaped his attention. ${ }^{13}$ This absence arguably becomes paramount for Budny's anti-Catholic stance, especially if taken into account with his interest in the text of the epiclesis (the invocation of the Spirit by the priest), partially underlined: "Then having sanctified ourselves by these spiritual Hymns, we beseech the merciful God to send forth His Holy Spirit upon the gifts lying before Him; that He may make the Bread the Body of Christ, and the Wine the Blood of Christ; for whatsoever the Holy Ghost has touched, is surely sanctified and changed." Budny's attention to this passage stems from his realization of the liturgical differences between the eastern Christian tradition, which prescribes that the change of the eucharistic elements into the Body and Blood of Christ is completed in the moment of the epiclesis, and the western tradition, which considers the sacrament of the eucharist valid during the words of its institution, based on the words of Jesus during the Last Supper, 1 Cor. 1:2425. Cyril's explicit mention of the epiclesis has proven challenging for Catholic theologians (Kern, Zolotoi vek 147). Budny arguably suspected a deliberate omission of another passage on epiclesis in Grodziecki's translation of MC 1: "as the bread and wine of the Eucharist [before the holy invocation of the adorable Trinity] was simple bread and wine" (Cross 56). There, Budny inserts his own Latin translation of the missing fragment ante sanctam invocationem adorandae trinitatis, making a note "because it is so in the Greek text" (Biii). Lesser emphasis on the invocation of the Spirit in the Catholic liturgy is connected to the heightened role of the priest who

\footnotetext{
11 For sources questioning Cyril's orthodoxy, and for a general discussion of Cyril's position toward Arianism, see Drijvers 181-86.

12 For possible interpretations of this absence, see Cutrone 56-64; Doval 150-61; Yarnold 41-42.

13 The institution narrative was lacking in the earliest surviving testimony to the Antitrinitarian eucharistic liturgy-Piotr Morzkowski's Ecclesiastical Polity (1646) (Petkūnas, "Polish and Lithuanian" 122).
} 
administers the sacrament in persona Christi (Kern, Evkharistiia 239). The omission of the institution narrative in the anaphora sequence might have been interpreted by Budny as a lack of placing special efficacy on the actions of the priest in Cyril's description of the eucharistic rite, and, in turn, might have served Budny's anticlerical and antichristological stance.

The omission of prayers "for soldiers and allies" in the intercessions part of Cyril's anaphora in Grodziecki's translation of MC 5 was likely unacceptable to Budny, as he began to polemicize against the proponents of nonresistance among the Polish Brethren and to justify participation in war in his Catechism, as well as in his On the Defense of the Sword (Diiiv).

Finally, whereas Budny's suspicions toward the Latin translation may be a reaction to the Council of Trent's establishment of the authenticity of the Vulgate, Budny was far from proclaiming the veritas graeca; for example, in his biblical translations: "no wise person says that the Latin books should be corrected on basis of the Greek ones" (Budny, Nowy Testament Ciiiiv-Cv). Consider Budny's critical reading of the Latin text in the beginning of MC 1, which provides a description of the movement from the Vestibule of the Holy Sepulchre Church into the Baptistery during the preliminary rites before baptism. Budny strikes out the word vespere in the beginning of the sentence "Vespere ingressi estis in porticum domus baptisterii ...," which was meant to imply: "In the evening, ye entered into the outer hall of the Baptistery." Budny replaces the word vespere with the word primum ("first," which seems to have displeased a subsequent reader who, in turn, struck out that word) and suggests his own reading in the margin that treats vespere as adjacent to the previous sentence: "ut quem illo vespere in vobis facta est, baptismi vim perspicatis" (Bi). By doing so, Budny utilizes the currently accepted reading "that ye may know the deep meaning to you-ward of what was done on that evening of your baptism. First, ye entered in the outer hall." Curiously, the 1560 Greek text does not support Budny's reading, placing the

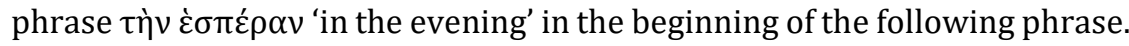
Could that imply that Budny added textual evidence from another manuscript? Or, perhaps, this suggests his familiarity with the 1564 edition of the MC, which uses "Primum ingressi estis ..." (S. Patris Nostri . . Catecheses Y)? ${ }^{14}$ The first conjecture would corroborate the suggestion that Budny did not exclude the possibility of the Greek texts being corrupt. In other words, he did not aim at finding or establishing the correct variant of a text (for him there was none, as all were corrupt, and any siding with a

14 It has been hypothesized that during his time as a student in KrólewiecKönigsberg, Budny might have met or known, however transitorily, the humanistic circle, of which one of the members was the aforementioned Jakub Uchański, the discoverer and translator of Cyril. It may also have been in Królewiec-Königsberg that Budny first began to harbour Antitrinitarian ideas (Pliss 1150-51). 
particular version was contextual). However, the role of Budny's marginalia in promoting the culture of criticism and correction cannot be underestimated.

I conclude this discussion of Budny's notes by touching briefly upon other Slavic readers of Cyril of Jerusalem. Cyril's sermons were later used among the Orthodox in Ruthenia and Muscovy as a polemical tool against the Catholic Church. In 1596, Stefan Zyzanii published his Kazan'e (Sermon of Saint Cyril, Patriarch of Jerusalem, on Antichrist), which was for a long time misattributed to Cyril of Jerusalem, although it was apparently Zyzanii's reworking of the original text of Cyril's 15th Catechetical lecture (Zyzanii). Zyzanii, drawing on the book De Papa Romano (1594) written by the Dutch Calvinist theologian Sibrandus Lubbertus, published Kazan'e immediately following the Union of Brest in order to support the view that the Pope was the Antichrist.

In seventeenth-century Muscovy, Cyril's Sermons were translated by the "Grecophile" monk Evfimii of Chudov. Olga B. Strakhov refers to two extant manuscripts with the translation (113). These are Sinod. 133 from the State Historical Museum in Moscow (Gorskii and Nevostruev 63-68) and SPB DA no. 1 from the National Library of Russia (Rodosskii 24-26). Evfimii, also familiar with Kazan'e (Strakhov 287), used Grodziecki's translation through its variant reworked by Jean Prévost, in addition to an old Slavonic translation, occasionally preserving the text, but also "modernizing it" (Vaillant 285). There are a number of parallels between Budny's notes and Evfimii's translation. While Budny notes that the underlined phrase in "et per hosce tantos dolores, mihi nihil eiusmodi patienti salutem confert" (Civ) is not contained in the Greek text (in Graeco non invenitur), Evfimii also omits it in his translation: "Христос на пречистых своих руках и ногах гвозди

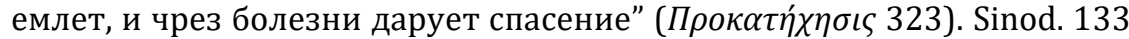
additionally contains a confutation of Polish and Latin translations of the Church Fathers, as "there are no Latin and Polish books without heresy and there exist none which would not be adverse to our [i.e. Orthodox] church: in some places it is manifest, in others, concealed and insidious" (Strakhov 113-14, 287). The Orthodox writer aims at refuting the Catholic dogma of filioque as "heresy" in a manner similar to Budny's attack from an Antitrinitarian perspective. What we observe here are curious but far from uncommon instances of rapprochement between the Orthodox and Antitrinitarian remonstrative readings of texts and translations with proCatholic agenda. 


\section{BUDNY As GLOSSATOR: ARS EXCERPENDI AND THE ARCHAEOLOGY OF READING}

A re-evaluation of the importance of the study of marginalia and glosses, ${ }^{15}$ as independent of the study of the text they accompany, and the questioning of "the bias against writing in books" are part of a larger trend in the reevaluation of various paratexts: footnotes, prefaces, etc. (Sherman, Used Books 155). Researchers have become "alert to the semiotic value of the entire Renaissance book, and not just the previously privileged authorial text" (Saenger 13). The sixteenth century was "the age of intense annotatorial activity" (Sherman, John Dee 80), as well as of diverse "scenes of reading" (Grafton and Sherman 213). Books belonging to early modern authors and carrying their notes and marginalia provide us with invaluable information regarding their ways of reading, selecting, noting, and organizing knowledge, as well as their self-fashioning. The evolution of these knowledge management strategies cannot be properly understood without analyzing marginalia creation as part of the reading process.

Recent studies have paid increasingly more attention to the figures of a reader-excerptor, which can be encountered in writings old and new. Reading with an aim to refurnish, reframe, inscribe another reader's ideas by inserting marginalia might seem suspicious to contemporary tastes and, more importantly, to contemporary research practices (Cevolini, De arte excerpendi 5; Minzetanu 32). The citation method of ars excerpendi, however, has gained increasing poetic and literary credibility, especially due to a fascination with the phenomena of palimpsests and centos in recent philosophical literature. This has led scholars to several far-reaching conclusions regarding the practice of marginal notetaking. Among those conclusions, first, on the theoretical level, is "the gloss transcends the text" (Lipking 611). Hence while an analysis of the text might be valuable, an examination of marginal notes usually reveals a no less valuable meta-logic of the reader. Second, marginal notes allow us to re-examine the interactions between the book and its reader; glossing "demonstrates that the place surrounding print is not a vacuum but a plenum" (Lipking 613). In other words, the book and its text serve not simply as a source of information, they are meant to be interacted with, written in, reflected on, and possibly contradicted. Marginalia can reverse the relationship between the text and the comment, as we saw in the case of Budny. While he was a meticulous and a respectful reader on many accounts, very often he would use the original text as means to build or corroborate the logic of his own narrative-a logic that we can at least partially surmise in his marginalia. Finally, marginalia

15 While I am aware of the important distinctions between marginalia and glosses made by Lawrence Lipking, in this paper I often use the words synonymously. 
reveal certain cultural trends, otherwise invisible. For example, in the South Slavic culture, the practice of marginal notetaking marked "the transition from enumeration to rudimentary forms of self-narration" (Petrovszky 499).

Although ars excerpendi practices can be traced back to antiquity, their development and refinement in the modern era are closely linked to the proliferation of knowledge and "information overload" (Blair). The paradox of such methods of reading is that on the one hand it seems like mere plagiarism, but on the other, it has a close affinity to the practices of the digital age, where the readers seek to find themselves, using the citations as building blocks to re-construe, or rather construe the self, present the self through the text, which in turn is arranged from citations taken from another text. In that respect, ars excerpendi can be paradoxically viewed as an ultimately original practice: "information-retrieval is a selective performance; in turn, selection is a highly personalized activity" (Cevolini, "Knowledge Management Evolution" 4). Thus, the combined practices of ars excerpendi and marginal notetaking inevitably shift the focus from the text itself to the logic of the reader. Marginalia are liminal texts: the liminality of a smaller text commenting on a larger text "mediates between the world of the text and the world of the reader" (Saenger 16).

Due to the influence of Catholic and Protestant traditions, marginal commentary was much more widespread in Ruthenia, than in Muscovy (Kudriavtsev 63). The use of marginalia could also be attributed to the influence of the Talmudic tradition (Kudriavtsev 63), which was most certainly the case with Budny (Budny, Nowy Testament Diiiv). Budny produced marginalia both as an author, in his treatises and biblical translations, and as a reader. In the former instance, his marginalia clearly make him a key figure in the development of knowledge management in early modern Ruthenia. He specifically acknowledges the importance of margins as a space where he could provide his translations for better understanding among his readers, barring occasions where the margins were too narrow (Budny, Nowy Testament D). Moreover, Budny avails himself of margins as a space of communication with his readers, where he personally addresses them. For example, he reminds them of the rules of pronouncing Hebrew sounds in a note starting with: "remember, o reader" (Pomni, czytelniku...) (Budny, O przedniejszych 35). The margins serve not only as a means to structure or supplement the text, they are employed dialogically and serve as a "meeting point," a place with importance equal to the main text and, moreover, with its own referentiality: "You have a note above, regarding what antithesis is" (Antithesis co jest, masz wyszej przypisek) (Budny, O przedniejszych 104).

However, the dearth of information on Budny's library resulted in much less scholarly attention paid to him as a reader. Budny is deemed to have possessed an extensive library, but his reading strategies undoubtedly 
informed his interest in creating his own printed marginal commentaries, and, as shown earlier, his works in general: "marginal annotations ... formed the basis for future composition by the reader himself" (Visser 100). Even when annotating resulted in scribal errors and subsequent theological confusion, he justified it on the grounds that annotating is a common practice for people who read books "attentively," "with diligence" (pilno) (Budny, Nowy Testament Gg iiii). Budny as a suspicious glossator, as a critical, subversive annotator who engages in what one could call "spectacularly discourteous acts of reading" (Zwicker 190) - this is yet another avatar of this radical thinker, whose annotations shed light on the early modern Slavic "archeology of reading" ("What Is the Archeology of Reading?").

Given the paucity of marginalia, it is especially worthy to note how Budny approached reading as practice at a theoretical level. His motto, "consult the Greek version here and everywhere," is a testimony about the complicated ways this thinker interacted with texts as an excerptor, appropriating citations with the goal of reusing and reutilizing them.

Budny likely used the Mystagogical Catechisms as a valuable source of information while working on his biblical translations and comments; these marginalia were a private intellectual workshop, where Budny could formulate and test his theological and philological ideas and his radical religious program. In his 1563 letter to Bullinger, Budny mentions reading the works of Thomas Aquinas, Peter Lombard, George of Trebizond, but bemoans the books being scarce (huc ad nos aegre perveniant libri) (Littera ad H. Bullingerum). This statement must have been either a topos modestiae, or a (barely) hidden sarcasm, as in the 1574 New Testament, his opus magnum, Budny refers to the wealth of sources he used while preparing the edition: works of "various correctors, commentators, theologians, historians, and different other authors or writers," and the books that he was able to "procure" at that time (Nowy Testament Dv). Despite his vehement rebuke against the Church Fathers as "know-it-alls" (mędrkowie) and "useless theologians" (Budny, O przedniejszych 190), he mentions several church writers, such as Jerome, Tertullian, Eusebius of Caesarea, Epiphanius of Salamis, and "some others" as his sources (Budny, Nowy Testament Dv). Arguably, Cyril's book was among the ones he could "procure." Having extensively used both Greek and Latin patristics (Saverchanka 64; Sanko et al. 696-97) and having acknowledged their influence on the development of his Antitrinitarian views, Budny most likely had the MCs as his "silent source" (Merczyng 28). Already in the Catechism he contemplated publishing a separate work on the sacraments (Merczyng 23): could he have considered using Cyril there, should the plan have ever come to fruition? His work Contra Paedobaptismum (Against Infant Baptism), where he might have used Cyril's MC, is now considered lost (Pietrzyk, "Szymon Budny" 64). At any rate, exposing the practices of "manipulative translation" (Bałuk- 
Ulewiczowa), he himself becomes a manipulative reader, engaging in not just a non-compliant, but also a selective, dissimulative reading. Here, Budny's reading strategies, while undoubtedly revealing about his approach to textual interpretation, were nevertheless characteristic of the whole epoch; ironically but predictably, his own writings succumbed to the same manipulative reading and "anonymous use of the opponents' tradition," when they got to the library of the Muscovite Orthodox hieromonk and book corrector Ivan Nasedka, the "cunning fox," who used Budny's writings for arguments in his polemics against Danish Lutherans (Oparina 202).

Since the necessity of ars excerpendi stems from the necessity to deal with the ever-growing proliferation of knowledge-the "information overload"-early modernity saw a burst of techniques helping authors and readers deal with such overload. It is relatively easy to envisage Budny as a person who was fascinated with "multitudes" (or rather, multitudes of multitudes): multitudes of books, languages, sources, traditions, and authorities. Our understanding of Budny arguably benefits from taking this fascination into account, while discussing his reading, writing, and his rhetorical strategies and preferences. As an author who reached out far geographically, writing to learned contemporaries across Europe, as a scholar who argued for not ignoring any evidence but incorporating it, even if it comes from the most unlikely of sources, and as a translator switching between different linguistic and cultural worlds, Budny epitomized the intricate connection between ars excerpendi and ars dissimulandi. Dissimulation was his means of "taming the multitude." Inasmuch as expedient concealment became an option for religious minorities to survive persecution, dissimulative reading and writing became a possibility to survive in the post-Gutenberg reality, with its ever-increasing amount of texts, data, and information, but also with its ever-increasing general distrust of the printed word (Renswoude 411). Yet Budny's undeniable contribution to Slavic intellectual history was in making dissimulation strategies serve an even larger cause.

\section{LIVING ON THE MARGINS}

By way of conclusion, I return to the hypocriseos crimen accusation, which was cast against Wędrogowski and which revealed diverging stances toward hypocrisy and inconstancy among Budny and his co-religionists. While later Antitrinitarians accused Wędrogowski of "hypocrisy," what mattered to them was his inconstancy in faith which they attributed to a lack of loyalty to the community. This discrepancy between the inner self and the outer self was important in the context of a breach of collective trust, Wędrogowski's preference for one religious group over another. Hence, the language of 
"shame" appeared in Lubieniecki's accounts of Wędrogowski's vacillations: the shame before God was also taken to mean the "shame" of not being able to stick to the right group, which represented the "true" faith. While Budny also expressed his opprobrium, what seems to have mattered even more to him was the personal inconstancy of Wędrogowski and his lack of loyalty to individual ideals rather than a lack of loyalty to collective ideals. It is true that for a certain period of time Budny's ideas were in alignment with those of the circles he belonged to, but he often expressed a clear disagreement between himself and the community. What became of utmost priority for Budny was staying true to his ideas, whether or not they were supported by the community, and this dissension culminated in Budny's expulsion and double excommunication. Underlining this distinction is necessary, since it allows us to see how Budny could justify using dissimulation as a way to be able to adhere to his own inwardly held beliefs, while arguably expressing more conforming views on the outside, as deemed necessary. In the words of a contemporary philosopher, "truthful persons may have much to conceal, including their own intentions not to disclose what they are concealing" (MacIntyre). Such concealment is visible in Budny's approach as glossator and excerptor.

By examining the marginalia in the MCs and Budny's practices of expedient "reading for action," we become privy to a textual laboratory that reveals him to be a scholar who practices selective, dissimulative reading. Since marginalia are a "window into one of the most seemingly intimate human activities," it is tempting to say that here we finally have glimpse of the "real" Budny, rather than his elaborately constructed discursive persona (Clark). Access to Budny's library, as well as his marginalia, give us more than a privileged opportunity to examine the thinker's "workshop"; could they possibly reveal the "sincere" Budny? There is evidence that Budny considered the possibility that books with his marginalia might be read by someone else-namely his calligraphic writing in a bright red ink. This possibility is corroborated by the history of the social practices of reading in the Renaissance: it "was a public performance, rather than a private meditation, in its aims and character" (Jardine and Grafton 31). Annotations frequently served as a "common reference" for members of one's intellectual circle (Grafton 209).

Marginal notes are a unique type of paratext, as they are created by the reader, in contrast to the footnotes or annotations that are created by the author. Still, this type of paratext influences the literary process, as well as the reader's perception of the book (Isaievych 142). Budny's notes were often struck out by later readers-likely, unintended readers-as was the case with his derisive address to Grodziecki on p. Aiiiv. As many other early modern readers, Budny "wanted his notes to be recognized, to become part of the author's text . . . to actively participate in the creation of a new, and 
ever-changing, text" (Sherman, John Dee 89). It possible that the marginalia were also intended to create another layer of interpretation, another mask for the thinker whose views and ideas were often marginalized by his community and contemporaries. While Budny's marginalia reveal significant information about his reading and argumentation strategies, his hidden self remains concealed. 


\section{Works Cited}

Backus, Irena. "Some Fifteenth-and Sixteenth-Century Latin Translations of the Greek Fathers, c. 1440-1565: Basil of Caesarea by Trapezuntius, Argyropulos, Cornarus, and Strigel; Justin Martyr by Perionius, Gelenius, and Lange." Studia Patristica, vol. 18, no. 4, 1990, pp. 305-21.

Backus, Irena, and Benoît Gain. "Le Cardinal G. Sirleto (1514-1585), sa bibliothèque et ses traductions de Saint Basile." Mélanges de l'école française de Rome, vol. 98, no. 2, 1986, pp. 889-955.

Bałuk-Ulewiczowa, Teresa. "Goslicius' Englished Senator: An Anatomy of Manipulative Translation." Publishing Subversive Texts in Elizabethan England and the Polish-Lithuanian Commonwealth, edited by Teresa Bela et al., Brill, 2016, pp. 167-82.

Baum, Johann Wilhelm, et al., editors. Ioannis Calvini Opera Quae Supersunt Omnia. Vol. XX, Schwetschke, 1879.

Bihain, Ernest. La tradition manuscrite grecque des ouvres de Saint Cyrille de Jérusalem. 1966. Université catholique de Louvain, $\mathrm{PhD}$ dissertation.

Blair, Ann. "Reading Strategies for Coping with Information Overload ca. 1550-1700." Journal of the History of Ideas, vol. 64, no. 1, 2003, pp. 11-28. DOI: $10.2307 / 3654293$.

Bos, Jacques. "The Hidden Self of the Hypocrite." On the Edge of Truth and Honesty: Principles and Strategies of Fraud and Deceit in the Early Modern Period, edited by Toon van Houdt et al., Brill, 2002, pp. 65-84.

Budny, Szymon. Biblia to iest, kśięgi Starego y Nowego przymierza, znowu z ięzyka ebreyskiego, grecskiego y laćińskiego, na polski przełożone. Daniel z Łęczycy, Niasvizh, 1572.

---. Katekhizis. Matsei Kaviachynski, Szymon Budny, Laurentsii Kryshkouski, Niasvizh, 1562.

---. Littera ad H. Bullingerum. Staatsarchiv des Kantons Zürich, 1563.

---. Nowy Testament znowu przełożony, a na wielu mieyscach za pewnemi dowodami od przysad przez Simona Budnego ocżyśćiony, y krotkiemi przypiskami po kraioch obiaśniony. Drukarnia Jana Kiszki, Łosk, 1574.

---. “O dzieciokrzczeństwie krótkie wypisanie: o zaczęciu sporu i polerowania około pirwszego sakramentu, to jest świętego ponurzenia w księstwie Litewskim a potem i w Polszcze." Odrodzenie i Reformacja w Polsce, vol. 31, 1986, pp. 102-09.

---. O przedniejszych wiary Chrystyjańskiej artykulech. Państwowe Wydawnictwo Naukowe, 1989.

---. O urzędzie miecza używającem. Łosk, 1583.

Cevolini, Alberto. De arte excerpendi: imparare a dimenticare nella modernità. Olschki, 2006.

---. "Knowledge Management Evolution in Early Modern Europe: An Introduction." Forgetting Machines: Knowledge Management Evolution in Early Modern Europe, edited by Alberto Cevolini, Brill, 2016, pp. 1-33.

Clark, Frederic. "Marginalia and the Social Nature of Reading." The New York Society Library, 10 June 2015, https://www.nysoclib.org/blog/marginalia-and-socialnature-reading. Accessed 21 June 2021. 
Cross, Frank L., editor. St. Cyril of Jerusalem's Lectures on the Christian Sacraments: The Procatechesis and the Five Mystagogical Catecheses. Translated by R. W. Church, S.P.C.K., 1951.

Cutrone, Emmanuel J. "Cyril's Mystagogical Catecheses and the Evolution of the Jerusalem Anaphora." Orientalia Christiana Periodica, vol. 44, 1978, pp. 52-64.

Domański, Janusz, and Lech Szczucki. "Miscellanea Arianica." Archiwum historii filozofii i myśli społecznej, vol. 6, 1960, pp. 199-287.

Doval, Alexis J. Cyril of Jerusalem, Mystagogue: The Authorship of the Mystagogic Catecheses. Catholic U of America P, 2001.

Drijvers, Jan Willem. Cyril of Jerusalem: Bishop and City. Brill, 2004.

Formanowicz, Leon. Katalog druków polskich XVI-go wieku bibljoteki kapitulnej w Gnieźnie. Rolnicza Drukarnia i Księgarnia Nakładowa, 1930.

Gorskii, Aleksandr V., and Kapiton I. Nevostruev. Opisanie slavianskikh rukopisei Moskovskoi sinodal'noi biblioteki 2(2). Sinodal'naia tipografiia, 1859.

Grafton, Anthony. "The Humanist As Reader." A History of Reading in the West. Translated by Lydia G. Cochrane, edited by Guglielmo Cavallo and Roger Chartier, Massachusetts UP, 1999, pp. 179-212.

Grafton, Anthony, and William Sherman. "In the Margins of Josephus: Two Ways of Reading." International Journal of the Classical Tradition, vol. 23, no. 3, 2016, pp. 213-38. DOI: 10.1007/s12138-016-0400-z.

Guzowski, Piotr. "Pierwszy polski indeks ksiąg zakazanych.” Studia Podlaskie, vol. 12, Jan. 2002, pp. 173-202. DOI: 10.15290/sp.2002.12.07.

Hall, H. Ashley. Philip Melanchthon and the Cappadocians: A Reception of Greek Patristic Sources in the Sixteenth Century. Vandenhoeck \& Ruprecht, 2014.

Isaievych, Iaroslav D. Literaturna spadshchyna Ivana Fedorova. Vyshcha shkola, 1989. Ivanova, Maria. "'Sub Pallio...Latens' [Hiding under the Cover]: Technologies of Concealment in Early Modern Poland-Lithuania." The Polish Review, vol. 63, no. 2, 2018, pp. 26-46. DOI: 10.5406/polishreview.63.2.0026.

Jardine, Lisa, and Anthony Grafton. “'Studied for Action:' How Gabriel Harvey Read His Livy." Past and Present, no. 129, 1990, pp. 30-78.

Kadochnikova, Oksana G. Poucheniia Sviatitelia Kirilla Ierusalimskogo $v$ Drevneslavianskom perevode: lingvotekstologicheskii analiz. Ėditus, 2017.

Kamieniecki, Jan. Szymon Budny: zapomniana postać polskiej reformacji. Wydawnictwo Uniwersytetu Wrocławskiego, 2002.

Kantak, Kamil. “Księga z biblioteki Szymona Budnego.” Litwa i Ruś, vol. 3, no. 1, 1912, pp. 61-63.

Keen, Ralph. "The Fathers in Counter-Reformation Theology in the Pre-Tridentine Period." The Reception of the Church Fathers in the West: From the Carolingians to the Maurists, edited by Irena Backus, vol. 2, Brill, 1997, pp. 701-44.

Kern, Kiprian. Evkharistiia. YMCA Press, 1947.

---. Zolotoi vek sviatootecheskoi pis'mennosti: zhizn' i uchenie vostochnykh ottsov IV veka. 2nd ed., Palomnik, 1995.

Kryshkouski, Laurentsii, et al. "Przedmowa do dialogu z Żydem Tryfonem.” Święty Justyn filozof i męczennik. Apologia: dialog z Żydem Tryfonem. Księgarnia Uniwersytecka Fiszer i Majewski, 1926, pp. XCIII-CIII.

Kudriavtsev, Sergei A. "Marginalii v kirillicheskoi knizhnosti XVI-XVII vv." Ural'skii sbornik. Istoriia. Kul'tura. Religiia, vol. 6, 2005, pp. 60-74. 
Lipking, Lawrence. “The Marginal Gloss.” Critical Inquiry, vol. 3, no. 4, 1977, pp. 60955.

Lubieniecki, Stanisław. Historia reformationis polonicae. Freistadii [Amsterdam?], 1685.

---. History of the Polish Reformation: And Nine Related Documents. Translated by George Huntston Williams, Fortress Press, 1995.

Łuszczyńska, Magdalena. "So What Is Really in a Name? Theology of Etymology in Sixteenth-Century Arian Thought." A Question of Identity: Social, Political, and Historical Aspects of Identity Dynamics in Jewish and Other Contexts, edited by Dikla Rivlin Katz et al., De Gruyter, 2019, pp. 337-47.

MacIntyre, Alasdair. "Truthfulness, Lies, and Moral Philosophers: What Can We Learn from Mill and Kant?" The Tanner Lectures on Human Values, Princeton University, 6-7 April 1994, https://tannerlectures.utah.edu/documents/a-to$\mathrm{z} / \mathrm{m} /$ macintyre 1994.pdf. Accessed 22 June 2021.

Merczyng, Henryk. Szymon Budny jako krytyk tekstów biblijnych. Polska Akademia Umiejętności, 1913.

Minzetanu, Andrei. "La lecture citationnelle ou l'ars legendi comme ars excerpendi." Littérature, vol. 168, no. 4, Jan. 2012, pp. 31-42. DOI: 10.3917/litt.168.0031.

Muszyński, Michał. "Proweniencje Poloników XVI wieku w zbiorach Biblioteki Kórnickiej (uzupełnienia do 'katalogu' K. Piekarskiego).” Pamiętnik Biblioteki Kórnickiej, vol. 13, 1977, pp. 145-270.

Niesiecki, Kasper. Herbarz polski. Breitkopf i Haertel, 1839.

Oparina, Tat'iana A. Ivan Nasedka i polemicheskoe bogoslovie Kievskoi mitropolii. Nauka, 1998.

Paretski, Iakau I. Symon Budny. Vydavetstva BDU, 1975.

Pérez Goyena, Antonio. "Francisco Torres." The Catholic Encyclopedia, vol. 14, Robert Appleton Company, 1912, p. 783.

Petkūnas, Darius. Holy Communion Rites in the Polish and Lithuanian Reformed Agendas of the 16th and Early 17th Centuries. Klaipeddos Universitetas leidykla, 2007.

---. "Polish and Lithuanian Anti-Trinitarian Eucharistic Practice in the 16th and 17th Centuries." Suomen kirkkohistoriallisen seuran vuosikirja [Annals of the Finnish Society of Church History], vol. 95, 2005, pp. 100-34.

Petrovszky, Konrad. "Marginal Notes in South Slavic Written Culture: Between Practising Memory and Accounting for the Self." Cahiers du monde russe, vol. 58, no. 3, 2017, pp. 483-502.

Piédagnel, Auguste, editor. Catéchèses mystagogiques. Translated by Pierre Paris, Éditions du Cerf, 1966.

Piekarski, Kazimierz. Katalog Bibljoteki Kórnickiej: Polonica XVI-go wieku. Bibljoteka Kórnicka, 1929.

Pietrzyk, Zdzisław. "Książka z biblioteki Szymona Budnego." Kieleckie Studia Historyczne, vol. 11, 1993, pp. 57-61.

---. "Szymon Budny." Bibliotheca dissidentium: répertoire des non-conformistes religieux des seizième et dix-septième siècle: Antitrinitaires polonais II: Szymon Budny (Budnaeus), Pierre Statorius (I'ancien), Christian Francken, edited by André Séguenny, vol. 13, Koerner, 1991, pp. 8-94. 
Pliss, Vladimir I. "Simon Budnyi i iego sektantskaia i literaturnaia deiatel'nost' v Litve i Zapadnoi Rusi." Khristianskoe chtenie, vol. 9, 1914, pp. 1046-68.

Podokshin, Semen A. Skorina i Budnyi: ocherk filosofskikh vzgliadov. Nauka i tekhnika, 1974.

Renswoude, Irene van. "'The Word Once Sent Forth Can Never Come Back': Trust in Writing and the Dangers of Publication." Strategies of Writing: Studies on Text and Trust in the Middle Ages, edited by Petra Schulte et al., Brepols, 2008, pp. 393-413.

Rodosskii, Aleksei S. Opisanie 432-kh rukopisei, prinadlezhashchikh S.-Peterburgskoi dukhovnoi akademii i sostavliaiushchikh ee pervoe po vremeni sobranie. A. 0. Bashkov, 1893.

Saenger, Michael. The Commodification of Textual Engagements in the English Renaissance. Ashgate Publishing, 2006.

Sanko, Siarhei I., et al. Historyia filasofskai i hramadska-palitychnai dumki Belarusi. Belaruskaia navuka, 2010.

Saverchanka, Ivan V. Symon Budny: humanist i refarmatar. Universitetskae, 1993.

Sherman, William H. John Dee: The Politics of Reading and Writing in the English Renaissance. Massachusetts UP, 1995.

---. Used Books: Marking Readers in Renaissance England. Pennsylvania UP, 2009.

S. Patris Nostri Cyrilli Archiepiscopi Hierosolymorum, Catecheses Illuminatorum Hierosolymis XVIII. et v. Mystagogicae. Christophorus Plantin, 1564.

Stinger, Charles. "Italian Renaissance Learning and the Church Fathers." The Reception of the Church Fathers in the West: From the Carolingians to the Maurists, edited by Irena Backus, vol. 2, Brill, 1997, pp. 473-510.

Strakhov, Olga B. The Byzantine Culture in Muscovite Rus': The Case of Evfimii Chudovskii (1620-1705). Böhlau Verlag, 1998.

Syrokomla, Władysław. Dzieje literatury w Polsce od pierwiastkowych czasow do XVII wieku. 2nd ed., vol. 1, Gebethner i Wolff, 1875.

Szczucki, Lech. "Szymona Budnego relacja o początkach i rozwoju anabaptyzmu w zborze mniejszym." Odrodzenie i Reformacja w Polsce, vol. 31, 1986, pp. 93-109.

Taft, Robert F. "Byzantine Communion Spoons: A Review of the Evidence." Dumbarton Oaks Papers, vol. 50, 1996, pp. 209-38. DOI: 10.2307/1291745.

Taylor, Andrew W. "Diplomatic Transcription: The Transmission of Photius, Cyril and Theodoret in Mid-Sixteenth-Century Italy." International Journal of the Classical Tradition, vol. 27, 2020, pp. 403-26. DOI:10.1007/s12138-019-00550-2.

Touttée, Antoine-Augustin. S. Cyrilli Archiepiscopi Hierosolymitani Opera Quae Exstant Omnia. Typis Jacobi Vincent, 1720.

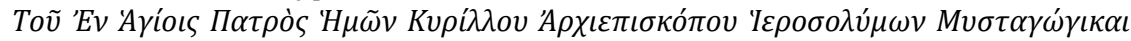

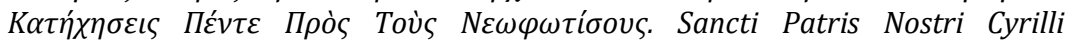
Archiepiscopi Hierosolymorum Mystagogicae Catecheses Quinque Ad Eos Qui Sunt Recens Illuminati. In aedibus Collegii Caesarii, Societatis Jesu, 1560.

Umiński, Józef. "The Counter-Reformation in Poland." The Cambridge History of Poland: From the Origins to Sobieski (to 1696), edited by William F. Reddaway et al., Cambridge UP, 1950, pp. 392-415.

Vaillant, André. "La traduction vieux-slave des catéchèses de Cyrille de Jérusalem: la deuxième catéchèse." Byzantinoslavica, vol. 4, no. 2, 1932, pp. 253-302. 
Visser, Arnoud S. Q. Reading Augustine in the Reformation: The Flexibility of Intellectual Authority in Europe, 1500-1620. Oxford UP, 2011.

Weber, Nicholas A. "Guglielmo Sirleto." The Catholic Encyclopedia, vol. 14, Robert Appleton Company, 1912, p. 27.

Węgierski, Andrzej. Libri Quatuor Slavoniae Reformatae Continentes Historiam Ecclesiasticam Ecclesiarum Slavonicarum, Inprimis Polonicarum, Bohemicarum, Lithuanicarum, Russicarum, Prussicarum, Moravicarum, \&c. Ab Apostolorum tempore usque ad nostra tempora; Quibus additur Appendix variorum monumentorum ad res ecclesiasticas Slavoniæ pertinentium . . . . Amsterdam, 1679.

"What Is the Archeology of Reading?" The Archeology of Reading. www.archaeologyofreading.org/what-is-the-archaeology-of-reading/. Accessed 10 June 2020.

Williams, George Huntston. The Radical Reformation. The Westminster Press, 1962.

Yarnold, Edward. Cyril of Jerusalem. Routledge, 2000.

Zwicker, Steven N. "Habits of Reading and Early Modern Literary Culture." The Cambridge History of Early Modern English Literature, edited by David Loewenstein and Janel Mueller, Cambridge UP, 2003, pp. 170-98. DOI: 10.1017/CHOL9780521631563.

Zyzanii, Stefan. Kazan'e sviatogo Kirilla patriarkha ierusalimskogo, o antikhriste $i$ znakakh ego. Brotherhood of the Holy Trinity, Vilnius, 1596.

Archive

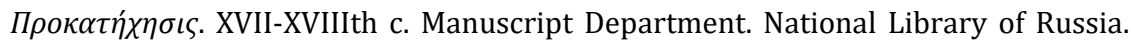
SPB DA no. 1. 